\title{
- PAPEL DO CONTADOR NA CONSCIENTIZAÇÃO DO CONTRIBUINTE PARA O EXERCÍCIO DA CIDADANIA FISCAL MEDIANTE A APLICAÇÃO DE DEDUÇÕES NA DIRPF
}

\section{ARTIGO ORIGINAL}

LIMA, Franknauria Guilherme Da Silva ${ }^{1}$

RABELO, Gerson Muniz ${ }^{2}$

LIMA, Franknauria Guilherme Da Silva. RABELO, Gerson Muniz. O papel do contador na conscientização do contribuinte para o exercício da cidadania fiscal mediante a aplicação de deduções na DIRPF. Revista Científica Multidisciplinar Núcleo do Conhecimento. Ano 04, Ed. 09, Vol. 04, pp. 175-201. Setembro de 2019. ISSN: 2448-0959,

Link de acesso: https://www.nucleodoconhecimento.com.br/contabilidade/papel-do-contador

\section{RESUMO}

No Brasil existem diferentes formas de incentivos ficais, dentre eles o mais acessível a todos contribuintes de Imposto de Renda são as doações incentivadas, por meio da DIRPF. Essa pesquisa busca analisar o papel do contador na conscientização do contribuinte para o exercício da cidadania fiscal mediante a aplicação de deduções na DIRPF em Boa Vista - RR. A metodologia utilizada foi a análise qualitativa exploratória, por meio do questionário estruturado, empregado através da plataforma

${ }^{1}$ Especialização Lato Sensu MBA em Auditoria Fiscal e Tributária pela Faculdade Atual da Amazônia - Centro Universitário Estácio da Amazônia, Boa Vista - RR, Brasil. Graduada em Ciências Contábeis pela Faculdade Atual da Amazônia - Centro Universitário Estácio da Amazônia, Boa Vista - RR, Brasil.

${ }^{2}$ Bacharel em administração pela universidade federal do amazonas - UFAM, Manaus - AM. Ensino Técnico em Contabilidade Escola Estadual Vital de Mendonça, Itacoatiara - AM. 
virtual SurveyMonkey, com perguntas abertas e fechadas. Utilizou-se como método para levantamento dos dados a pesquisa documental, por meio de lista de escritórios de contabilidade localizados em Boa Vista Roraima, disponibilizada pelo CRC-RR. Os resultados da pesquisa expõem que a maioria dos escritórios de contabilidade faz a DIRPF no modelo completo com doações incentivadas, a maioria possui tempo de atuação entre 5 a 15 anos no mercado contábil. Por fim a pergunta significativa acerca da opinião dos contadores quanto o seu papel em informar aos contribuintes a respeito das doações incentivadas, obteve-se um empate de respostas entre os entrevistados. Concluiu-se que, foi possível identificar que o profissional contábil em Boa Vista-RR, tradicionalmente, não se identifica como incentivador social, apesar de possuir o conhecimento e a oportunidade para orientar seus clientes.

Palavras chave: DIRF, doação incentivada, fundos assistenciais, contador, Imposto de Renda.

\section{INTRODUÇÃO}

A convivência em sociedade desponta, desde os primórdios, como um dos grandes desafios à sobrevivência da humanidade como uma espécie a ser perpetuada no tempo. Por óbvio, a convivência em sociedade possui incontáveis variáveis e complexidade extrema, assim surge o Estado para desenvolver o papel de controle, manutenção da organização social, o desenvolvimento nacional, além de promover o bem de todos.

Neste sentido, para que o Estado possa atingir os seus fins e se auto promover utiliza vários recursos. Segundo Sabbag (2012) a principal fonte de receitas públicas para alcançar o bem comum é a cobrança de tributos. Dentre os tributos de competência da união, destaca-se o Imposto de renda (IR) por tratar-se de um imposto sobre a aquisição da disponibilidade econômica (renda) e dos proventos de qualquer natureza.

Conforme Chimenti (2012), a função social do IR é a redistribuição da Renda que será aplicada na gestão dos serviços públicos federais, estaduais e municipais com a 
disponibilização de serviços na saúde, educação, cultura, esporte e outros. Ocorre que, esses serviços ofertados à população são deficitários e insuficientes a atender à crescente demanda social.

Deste modo, o Estado lança mão de mecanismos fiscais para fomentar no plano teórico a cidadania e cria oportunidades aos contribuintes atuarem ativamente como cidadãos, através de doações com a opção de deduzir do Imposto de Renda, tanto de pessoas físicas quanto de jurídicas. Para tanto é necessário destacar que as doações podem ser realizadas mediante aplicação direta aos fundos ou nas instituições sociais específicas e também podem ser efetuadas no momento da Declaração do Imposto de Renda da Pessoa Física (DIRPF).

Os incentivos fiscais são distribuídos por área: formação universitária, investimento social, cultural, esporte e saúde. As pessoas físicas podem deduzir até $6 \%$ do imposto de renda quando efetuam doações aos Fundo do Direito da Criança e Adolescente, Fundo do Idoso e até 1\% aos programas nacionais PRONAS/PCD (Programa Nacional de Apoio à Atenção da Saúde da Pessoa com Deficiência), PRONON (Programa Nacional de Apoio à Atenção Oncológica)

Por meio de relatório "Doações aos Fundos dos Direitos da Criança e do Adolescente. Primeiro repasse." divulgado pela Receita Federal (2018) é possível evidenciar que existe uma única instituição habilitada, em Boa Vista-RR, no Fundo dos Direitos da Criança e do Adolescente.

Observa-se, ainda, neste contexto que a opção por doação com dedução no Imposto de Renda ainda possui pouca adesão entre as pessoas físicas, no tocante ao Fundo dos Direitos da Criança e do Adolescente, em Boa Vista-Roraima (RECEITA FEDERAL, 2018). Em virtude disso é necessário frisar que a profissão contábil está fortemente ligada com a DIRPF, uma vez que muitos contribuintes fazem procura de tal profissional para a elaboração da declaração, já que ele é portador do conhecimento normativo do referido assunto. 
Mediante ao exposto, esta pesquisa se propôs a responder a seguinte questão: $\mathrm{O}$ contador exerce o papel de incentivador no exercício da cidadania fiscal, mediante a aplicação de deduções na DIRPF em Boa Vista - RR? Portanto, a presente pesquisa tem como objetivo analisar o papel do contador na conscientização do contribuinte para o exercício da cidadania fiscal mediante a aplicação de deduções na DIRPF em Boa Vista - RR.

Por meio de uma pesquisa exploratória realizada nos escritórios de contabilidade na cidade de Boa Vista -RR, obtida a relação mediante ofício ao Conselho Regional de Contabilidade (CRC) de Boa Vista-RR, em que constavam 98 escritórios, aplicou-se um questionário com 13 perguntas alternadas entre abertas e fechadas com intuito de alcançar o objetivo proposto pelo estudo.

Consequentemente a relevância social da pesquisa decorre do fato de realizar um estudo que contribua para prática de doações como incentivo a realização de projetos sociais em Boa Vista-Roraima. Atrelado a isso o estudo pretende sensibilizar os acadêmicos e profissionais da contabilidade na procura de informar como o contribuinte do Imposto de Renda Pessoa Física (IRPF) pode exercer a cidadania fiscal.

E neste artigo compõe-se de cinco seções sendo a Introdução a primeira delas, (II) Fundamentação teórica, (III) Procedimentos metodológicos, (IV) Análise de dados e (V) Considerações Finais.

A Introdução aborda o tema de forma geral, traz objetivos, justificativa e a estrutura do trabalho. No segundo tópico traz a fundamentação teórica, no qual possui o propósito de explanar sobre o imposto de renda, deduções e fundos públicos. Neste primeiro momento será enfatizado os benefícios das doações aos fundos e programas destinado aos contribuintes de imposto de renda pessoas físicas.

O terceiro tópico, terá como enfoque os procedimentos metodológicos aplicados no decurso da pesquisa, com base nos autores renomados e de grande marco histórico. No quarto tópico trata-se da análise de dados obtidos mediante o questionário 
aplicado aos contadores localizados em Boa Vista -RR. Por fim as considerações finais, no que concerne a resposta da pergunta questão desse estudo e a relação dos fatos verificados.

\section{FUNDAMENTAÇÃO TEÓRICA}

Em decorrência da inovação e originalidade da temática abordada no presente artigo científico existe uma flagrante carência de autores que estudem de forma enfática e aprofundada o papel do contador na sensibilização para o exercício da cidadania fiscal, mediante a aplicação de deduções na Declaração do Imposto de Renda Pessoa Física (DIRPF).

Em virtude das produções dos teóricos contábeis Conte \& Santos e Silvio Crepaldi \& Guilherme Crepaldi, cujas obras são os pilares de fundamentação teórica, que embasaram a edificação desta pesquisa, não é possível identificar uma produção rica e substancial, enfocando a temática aqui abordada. No entanto, os conceitos desenvolvidos por aqueles renomados teóricos, são necessários para que as seguintes subseções sejam aqui desenvolvidas.

\subsection{IMPOSTO DE RENDA}

Antes de adentrar propriamente na temática proposta, faz-se necessário compreender que um conjunto de conceitos teóricos sobre os quais se construiu o atual cenário da tributação que busca o bem-estar social. Neste interim, por tanto, é impossível não destacar o papel interventor do Estado.

Desta maneira, Conte \& Santos (2014, p. 10) afirma que o Estado está "em busca constante de manter a ordem e propiciar bem-estar coletivo (...)" e Silvio Crepaldi \& Guilherme Crepaldi (2013, p.26) enfatizam "(...) pode-se dizer que a finalidade [do Estado] é a realização do bem comum e a promoção do bem-estar social por meio do atendimento das necessidades sociais". Mas, para exercer o papel de promotor do bem-estar o Estado precisa exercer atividades financeiras para custear as tais necessidades sociais. 
Dessa forma, Silvio Crepaldi \& Guilherme Crepaldi (2013, p.26) afirmam, ainda, que "entende-se como atividade financeira do Estado o conjunto de atos executados pelo poder público voltados para obtenção, a gestão e a aplicação de recursos pecuniários destinados a viabilizar soluções para as necessidades públicas". Está vinculada à procura de satisfazer as carências publicas básicas por meio a prestação de serviços públicos, incremento as ações de interesse público e social.

Ainda nesta linha de pensamento, Sabbag (2012, p,40) leciona que o Estado arrecada recursos para manter a sua estrutura para oferecer aos cidadãos, conforme normatiza 0 art. $3^{0}$ da Constituição Federal, dentre outros uma sociedade livre e justa, erradicação da pobreza e da marginalização, redução das desigualdades sociais e regionais e promoção do bem-estar da coletividade:

A cobrança de tributos se mostra como a principal fonte das receitas públicas, voltadas ao atingimento dos objetivos fundamentais, insertos no art. $3^{\circ}$ da Constituição Federal, tais como a construção sociedade livre, justa e solidária, a garantia do desenvolvimento nacional, erradicação da pobreza e da marginalização, tendente à redução das desigualdades sociais e regionais, bem como a promoção do bem-estar da coletividade.

Sendo um assunto complexo e de extrema importância, a tributação ganha um espaço de destaque não apenas entre os teóricos da doutrina contábil, mas, também, entre os juristas, pois sua fonte primária é a lei, pois é o único canal apto a produzir diretamente obrigações e proibições de fazer ou não fazer. Desta forma entende-se que seja qualquer veículo normativo que exprima a vontade popular.

Castardo (2017) ensina que o direito tributário “(...) impõe um comando normativo geral e informador para as demais entidades políticas", assim, o direito tributário, tem como objeto de estudos as normas que criam os tributos e seus fatos geradores, que regulamentam as formas de arrecadação e de destinação dos tributos e a regulamentação da relação jurídica entre o contribuinte e o Estado.

Dito isto, passa-se a primeira das subseções inicialmente citadas, que seja, o Imposto de Renda - Imposto sobre a renda e proventos de qualquer natureza (IR). Um aspecto relevante sobre o IR é o histórico, pois, a primeira vez que surgiu um imposto 
assemelhado ao que seria o atual Imposto de Renda, foi a "contribuição para as pessoas que recebiam vencimentos dos cofres público", os atuais funcionários públicos. Criado em 1843, no reinado de D. Pedro II, e que subsistiu por apenas dois anos e foi extinta. (NÓBREGA, 2014).

No entanto, o nascimento legal do IR deu-se com a instituição do Imposto Geral pela Lei 4.625/1922. Em 1926, o Brasil passou a adotar o Sistema Francês de tributação e a obrigatoriedade da entrega de declaração dos rendimentos pelos contribuintes (NÓBREGA, 2014 p. 31 e 32). Ao longo dos anos ocorreram inúmeras adaptações nas regras de tributação do imposto de renda, até chegar aos moldes atualmente conhecidos.

$\mathrm{Na}$ atualidade, Barreirinhas (2014), explana que o IR tem principal função fiscal, mas ao mesmo tempo de distribuição de renda. Do mesmo modo Sabbag (2012) afirma que deve ser utilizada a fim de promover a adequada redistribuição de renda. Sendo o IR, disposto no art. 153 da CF como um imposto federal, cabe a União sua instituição, fiscalização e arrecadação.

Ainda que seja um tributo de competência da União, o imposto de renda arrecadado não é por este totalmente apropriado, pois o sistema tributário normatiza a repartição de parcela da arrecadação tributária entre os entes públicos, ou seja, União, Estados, Distrito Federal e Municípios (AMARO, 2017).

A partilha da tributação é tema pacifico entre os autores e também normatizado na legislação brasileira. Como é possível observar na narrativa Amaro (2017, p 118) "o produto da arrecadação de determinados tributos, [das quais o imposto de renda está inserido], instituído por certo ente político, não é por este apropriado, ou não é por ele totalmente apropriado, mas partilhado com outros entes políticos".

Também seguindo nesta mesma linha de raciocínio Silvio Crepaldi \& Guilherme Crepaldi (2013) afirmam que o sistema tributário institui, arrecada e distribui o imposto na proporção de percentagem do valor arrecadado entre as entidades que a compõem. 
O IR possui duas formas de repasse no Brasil, quais sejam, a direta e a indireta. $\mathrm{O}$ imposto de renda é repassado, na forma direta, ou seja, $100 \%$ do valor arrecadado aos Estados, Distrito Federal e Municípios quando incidente na fonte pagadora, sobre rendimentos pagos a qualquer título por eles, suas autarquias e fundações que instituírem e mantiverem (art. 157, I e 158, I, da CF).

Na participação indireta, o imposto de renda, conforme à luz da Constituição nos incisos I e II do art. 159 normatiza, é repassado por meio de "fundos de participação" em que os Estados e o Distrito Federal recebem 21,5\% sobre a arrecadação e os Municípios, 23,5\%, Silvio Crepaldi \& Guilherme Crepaldi (2013).

No entanto, antes de partilhar o imposto os entes federativos precisam arrecadar o tributo. Essa arrecadação para Amaro (2017) é gerada por um fato anteriormente descrito em lei que dada a ocorrência irá gerar uma obrigação. Conforme o autor citado acima, ressalta que no art. 114 do Código Tributário Nacional (CTN, 2012) "o fato gerador da obrigação tributária principal é a situação definida em lei como necessária e suficiente à sua ocorrência".

O fato gerador do imposto é a aquisição da disponibilidade econômica ou jurídica da renda ou provento. A despeito disso Barreirinha (2014) diz que qualquer aumento patrimonial, ainda que não seja pela exploração do capital ou do trabalho, sofrerá incidência. O fato gerador da pessoa física, afirma Sabbag (2012), é o rendimento líquido, ou seja, a renda bruta de todas as rendas e proventos adquiridos durante 0 ano-base, descontando as despesas e gastos autorizados pela lei.

Mesmo ocorrendo o fato gerador, nos termos do art. 153 da Constituição Federal (CF), o imposto de renda deve atender aos critérios da progressividade, generalidade e universalidade. De acordo com o princípio da progressividade "as alíquotas devem ser maiores conforme seja maior a base de cálculo" (BARREIRINHAS, 2014). Por outro lado para Chimenti (2012) o principio permite que as alíquotas sejam graduadas, conforme a capacidade econômica do contribuinte. 
Pelo princípio da generalidade, o tributo incide sobre todas as pessoas que tiverem acréscimos patrimoniais. Partindo deste principio, Sabbag (2012) indica que todos os contribuintes estão sujeitos no momento que houver a incidência da exação. Segundo - Princípio da Universalidade abrange todas as pessoas, físicas ou jurídicas, independentemente da sua profissão, escolaridade (CHIMMENTI, 2012).

Deste modo, a caracterização do fato gerador, das bases de cálculos, a ser adotado para o Imposto de Renda é a aquisição de disponibilidade econômica ou jurídica de renda ou de proventos de qualquer natureza.

De acordo com o Código Tributário Nacional o vínculo tributário está relacionado entre o sujeito ativo que é a pessoa jurídica de direito público que tem a competência para instituir o tributo, portanto é quem exige o cumprimento da obrigação tributária e o sujeito passivo que é a pessoa física ou jurídica, titular de renda ou provento de qualquer natureza.

Sabbag (2012) entende que aquisição da disponibilidade econômica ou jurídica de renda, proveniente do capital, do trabalho, ou da junção de ambos, e de proventos de qualquer natureza, assim compreendido como acréscimo não englobado no conceito de renda. Não é preciso que tenha efetivado o recebimento da renda em dinheiro, apenas o crédito caracterizará a ocorrência da incidência.

Chimenti (2012) acrescenta que a renda consumida também sofrerá tributação. Quanto a disponibilidade econômica e jurídica, Eduardo Sabbag (2012), mostra que pode variar por efeito da renda de capital, da renda do trabalhador, da renda da combinação do capital e do trabalho e dos proventos de qualquer natureza.

Chimenti (2012) enuncia que a obtenção de disponibilidade econômica não representa necessariamente o rendimento efetivamente recebido sendo satisfatório que o contribuinte tenha adquirido o direito de crédito sobre ele, isto é, a disponibilidade jurídica.

Considerando Chimenti e Pierri (2012) a lei pode atribuir à fonte de renda pagadora reter do contribuinte o imposto de renda e repassar para a União figurando assim a 
fonte pagadora como responsável e o empregado como contribuinte. A omissão da retenção e recolhimento acarretará a fonte pagadora uma multa pelo não cumprimento da obrigação conforme pontua o art. 121, parágrafo único, II, do CTN (p.84,2012).

Vale ressaltar que Chimenti (2012) a obrigação de reter o valor relativo ao imposto de renda e o recolhimento tem seu prazo determinado. Ainda o autor citado, explica que o contribuinte pessoa física são todas as pessoas naturais que residem ou domiciliam no Brasil, que tenham recebidos rendimentos, e proventos, que tenham passado do limite da isenção, qualquer que seja sua nacionalidade, profissão, sexo ou estado civil.

\subsection{DEDUÇÕES}

Para Barreirinhas (2014) o contribuinte declara anualmente o imposto apresentando os rendimentos e despesas à Receita, afora os tributos recolhidos antecipadamente, como retenções na fonte e carne-leão. Após o preenchimento da declaração obtémse a base de cálculo do imposto. Deste valor sobrepõe uma alíquota expressa pela tabela progressiva em que a Receita Federal divulga corrigida anualmente.

Em conformidade com Barreirinhas (2014), Muller (2017) afirma que a Receita demonstra, pela tabela, as alíquotas de acordo com o montante apurado e suas devidas parcelas a deduzir e a partir da declaração o fisco verifica o valor a ser recolhido ou a ser restituído. Diante deste fato a Receita Federal disponibiliza ao contribuinte a opção de declarar em qual modelo melhor lhe convém. Os modelos são: Desconto Simplificado e por Deduções Legais.

O modelo de Desconto Simplificado tem por característica, assim demonstra Muller (2017), a substituição das deduções legais para a dedução de $20 \%$ dos rendimentos tributáveis, no limite de $R \$ 16.754,34$. Em contrapartida o outro modelo é o por Deduções Legais, também conhecida como completa, modelo pelo qual o contribuinte informa os seus rendimentos assim como as deduções legalmente permitidas (MULLER, 2017). 
As doações de incentivo foram criadas com a Lei no 4.357/64 que favorecia o desenvolvimento nos investimentos de cunho econômico e social no país e, deste modo, beneficiaria aos contribuintes a reduzir o imposto, caso fizesse uso deste incentivo fiscal. (NÓBREGA, 2014).

No que se refere Kiyoshi Harada (2001, p. 298, apud Sabbag, p. 274,2012) os incentivos fiscais tem sua destinação "a promover o desenvolvimento socioeconômico integrado do território nacional como um todo(....)." Diante de tal fato sua pratica pode ser exercida tanto pela pessoa jurídica como pessoa física.

Os incentivos fiscais evidenciados neste trabalho são as doações efetuadas aos fundos do Direito da Criança e Adolescente, Fundo do Idoso, (em qualquer âmbito seja ele distrital, estadual ou municipal), e também as doações ou patrocínio aos programas nacionais PRONAS/PCD (Programa Nacional de Apoio à Atenção da Saúde da Pessoa com Deficiência), PRONON (Programa Nacional de Apoio à Atenção Oncológica).

As doações para fundos que são controlados pelos Conselhos dos Direitos da Criança e do Adolescente e ao Fundo do Idoso obedecem ao limite global de $6 \%$ até o dia 31 de dezembro do ano-calendário. Aos incentivos fiscais destinados ao PRONAS/PCD e PRONOM as deduções estão limitadas a 1\% (no somatório 2\%), não estando sujeito ao limite global de $6 \%$ que incluem as doações no ano calendário aos demais fundos.

Há a possibilidade de usufruir do benefício fiscal doando diretamente na declaração de ajuste anual (DAA) permitida somente para o Fundo da Criança e do Adolescente no montante de até $3 \%$ do imposto devido apurado na declaração. Podendo utilizar os 3\% restante para doações ocorridas no ano-calendário totalizando o limite global de $6 \%$.

O contribuinte da receita na declaração de pessoa física que optar pela declaração completa poderá utilizar como dedução as doações para incentivos fiscais. Para quem fizer a doação, segundo o manual de incentivos fiscais do CRC-RS (2016), os incentivos fiscais relacionados a saúde têm o limite individual de 1\%, atingindo na 
soma a $2 \%$. Já os relacionados as áreas social, cultural e desportivas o incentivo fica limitado a $6 \%$ ao ano.

Conforme os autores (Barreirinha e Muller, 2014) o imposto de renda é um dos tributos que a União mais arrecada devido ao seu fato gerador que incide sobre a renda líquida, tributando de forma mais incisiva os rendimentos das classes mais alta. Tem como alíquotas proporcionais maiores à medida que a base de cálculos for maior.

A Receita Federal é o órgão responsável pela administração desse tributo e por meio deste órgão que os contribuintes pessoas físicas fazem sua Declaração de Imposto de Renda e por meio desta que podem exercer sua cidadania fiscal optando pela doação para dedução do imposto devido. (BARREIRINHA E MULLER, 2014)

\subsection{FUNDOS PÚBLICOS}

Segundo Zacher (apud SALET, 2015) o Estado de Bem-Estar Social é entendido como um Estado que proporciona justiça social por intermédio dos procedimentos e limites do Estado Democrático de Direito. A partir do Estado Social Brasileiro, houve inserção dos Fundos Públicos por meio da Lei 4.320/64 em que determina que os fundos especiais são criados com o intuito de movimentar recursos provenientes de receitas especificas como da saúde, da previdência, aplicados na área afim. (MELO e VALE, 2015),

Segundo Elias (2004, apud Melo e Vale, 2015), a partir das alterações ocorridas houve mudanças na área da seguridade social com a criação de fundos públicos, para financiar as ações do Estado no que cabe a proteção social da população. Ainda, Melo e Vale (2015) conceituam que os fundos são organizações institucionais para transmissão de recursos que aparecem como mecanismo de controle no âmbito financeiro e administrativo no período das reformas da administração pública, posteriormente somando função de controle político.

Alencar Júnior e Salvador (2015), baseados em Salvador (2012), apontam que o fundo público enlaça toda a capacidade de concentração de recursos que o Estado tem para 
agir na economia, tanto por meio das empresas públicas, pelo emprego de suas políticas monetária e fiscal, como também pelo orçamento público.

Conforme a temática exposta, ocorre que no ano de 1991, por meio da Lei № 8.242/91 criou-se o Conselho Nacional dos Direitos da Criança e do Adolescente (CONANDA) instituiu-se o Fundo Nacional para a Criança e ao Adolescente (FNCA) como seu suporte financeiro. O Fundo dos Direitos da Criança e Adolescente foi criado por Lei Federal para favorecer crianças e adolescentes. Formado por doações do próprio Poder Público assim como também por pessoas físicas e jurídicas.

Na Lei № 8.069/1990, Estatuto da Criança e do Adolescente, art. $3^{\circ}$ evidencia que a criança e do adolescente têm todos os direitos fundamentais intrínsecos a pessoa física, sem prejuízo da proteção integral de que se trata o Estatuto.

Sob o mesmo ponto de vista, de acordo com o referido Estatuto da Criança e Adolescente "têm direito à educação, visando ao pleno desenvolvimento de sua pessoa, preparo para o exercício da cidadania e qualificação para o trabalho" (BRASIL, 1990). E é o dever do Estado assegurá-lo.

Para tanto o Fundo dos Direitos da Criança e Adolescente tem como objetivo assegurar todos os direitos a que cabe à Criança e Adolescente, "além de colocá-los à salvo de toda a forma de negligência, discriminação, exploração, violência, crueldade e opressão" (CRC-RS,2016, p.59).

Por outro lado, cabe destacar, no que concerne aos idosos, o Fundo do Idoso. Tal fundo foi Instituído pela Lei № 12.213/10, tem como destinação financiamento de programas e ações referentes aos idosos com o objetivo de "assegurar os seus direitos sociais e criar condições para promover sua autonomia, integração e participação efetiva na sociedade" (BRASIL, 2010).

Nesta Lei a União autoriza os contribuintes, pessoas físicas e jurídicas, a doarem para os Fundos Municipais, Estaduais ou Federal do Idoso, desde que respeitadas as regras estabelecidas. $\mathrm{O}$ art. $230 \mathrm{da} \mathrm{CF} / 88$ defende a dignidade e bem-estar das 
pessoas idosas e garante o direito à vida como dever da família, da sociedade e do Estado.

Atualmente há dois Programas Federais direcionados para área de saúde no Brasil instituídas pela Lei 12715/2012. O PRONON visa a captação de recursos para aplicação na prevenção e combate ao câncer, e o PRONAS/PCD, visa a captação também, as quais serão posteriormente destinadas ao tratamento de deficiências. Enquanto o PRONON a captação é por intermédio de entidades sem fins lucrativos autorizadas previamente pelo Ministério da Saúde, o PRONAS/PCD capta por intermédio de entidades de direito privado sem fins lucrativos.

O PRONAS/PCD tem a finalidade de arrecadar e canalizar recursos para incentivar, desenvolver a prevenção e a reabilitação da pessoa com deficiência, física, motoras, auditivas, visuais, mentais, por meio de ações preventivas, diagnóstico precoce, tratamento, adaptação de órteses, próteses e meios que auxiliam a locomoção, em todo transcurso de vida.

PRONON e PRONAS/PCD visam projetos a Prestação de serviços medicoassistenciais, a formação, o treinamento e aperfeiçoamento de recurso humanos, a pesquisas clínicas, epidemiológicas e experimentais que são áreas prioritárias definidas pelo Ministério da Saúde para destinação dos recursos obtidos.

Diante do exposto observa-se que os fundos públicos foram instituídos a partir de um Estado que visa a justiça social através de direitos positivos que serve como disciplina e organização de uma sociedade a partir de um "Contrato Social". E, por intermédio da Declaração do Imposto de Renda de Pessoa Física, o Estado age como norte para garantir a atuação dos contribuintes em sua cidadania mediante doações como opção de dedução do imposto devido.

\section{PROCEDIMENTOS METODOLÓGICOS}

Esta pesquisa tem como objetivo analisar o papel do contador mediante aplicação de deduções na DIRPF. Em despeito disso Barros; Lehfeld (2000a, p. 14 apud 
PRODANOV, 2013 p. 42) afirmam que o intuito da pesquisa é procurar resolver problemas e encontrar soluções para as dúvidas por meio de procedimentos científicos.

Marconi \& Lakatos (2003, p 80) cita que "o conhecimento científico é real (factual) porque lida com ocorrências ou fatos". Para estas autoras (2003) a pesquisa tem como objetivo encontrar um caminho para conhecer a realidade ou mostrar verdades parciais, cuja técnica se faz por métodos formais e recurso de pensamento reflexivo.

Desta forma o trabalho tem seu enfoque qualitativo-exploratório que para Gil (2008, p. 27) "tem como principal finalidade desenvolver, esclarecer e modificar conceitos e ideias, tendo em vista a formulação de problemas mais precisos ou hipóteses pesquisáveis para estudo posteriores". Ao mesmo tempo que para uma pesquisa qualitativa "há uma relação entre o mundo real e o sujeito, isto é, um vínculo indissociável entre o mundo objetivo e a subjetividade do sujeito que não pode ser traduzido em números" (PRODANOV \& FREITAS, 2013 p. 70).

Oliveira (2000), considera o método qualitativo como o método mais exploratório na pesquisa cientifica, ele determina as categorias e atributos da pesquisa. Do mesmo modo Beuren (2006) diz que é comum o uso da abordagem qualitativa, na contabilidade, como tipologia de pesquisa. Segundo a mesma linha de pensamento, embora a contabilidade lide com números, ela é uma ciência social, o que fundamenta uma abordagem qualitativa.

Quanto ao procedimento operacional utilizou-se do tipo bibliográfico, documental e de levantamento. O bibliográfico a partir de materiais já publicados de livros, publicações em periódicos e escassos artigos científicos a respeito do tema. A despeito disto Prodanov \& Freitas (2009, p. 54) afirmam que este método tem o "objetivo de colocar o pesquisador em contato direto com todo o material já escrito sobre o assunto da pesquisa

No que concerne a pesquisa documental, Gil (2008) explana que a diferença que se tem com a pesquisa bibliográfica é a natureza das fontes, donde esta se utiliza de 
contribuições de diversos autores sobre determinados assuntos e aquela ainda não recebeu um tratamento analítico.

Outro método usado foi o de levantamento. Com base nos autores Prodanov \& Freitas (2009) é utilizado quando "envolve a interrogação direta das pessoas cujo comportamento desejamos conhecer através de algum tipo de questionário". Quanto ao método de levantamento survey esclarece Gil, (2011) o objetivo é interrogar diretamente as pessoas sobre a problemática levantada.

Tendo a contabilidade como uma ciência social, tornando este trabalho uma pesquisa social que para Gil (2008) abrange um universo em que se torna difícil considera-lo em sua totalidade, devido a isto foi utilizado uma parte em que compõe este universo. Empregou-se a amostragem não probabilística.

Foi obtido no Conselho Regional de Contabilidade uma listagem com as informações sobre os escritórios domiciliados em Boa Vista - RR, que foram contactados por telefone e e-mails.

As técnicas usadas para obtenção dos dados relevantes a este trabalho foram questionário, documentos impressos e eletrônicos. No que tange ao questionário, foi elaborado com perguntas abertas e fechadas que é uma técnica em que se sustenta em uma série de perguntas ordenadas com objetivo de coletas de dados (MARCONI \& LAKATOS, 2003).

O questionário aplicado realizou-se através do link de direcionamento para plataforma virtual do SurveyMonkey. Por meio desta disponibilizou-se recursos ilustrativos, gráficos, quantidades, percentuais, voltados a conclusão da análise de dados.

Os documentos impressos e eletrônicos e documentos oficiais que, baseado em Marconi \& Lakatos (2003 p. 183) "oferece meios para definir, resolver, não somente problemas já conhecidos, como também explorar novas áreas onde os problemas não se cristalizaram suficientemente", logo torna-se vantajoso visto que possibilita o conhecimento do passado, a investigação dos processos de mudança social e cultural, a obtenção de dados com menor custo. (GIL,2008). 
Marconi \& Lakatos (2003) afirma que toda pesquisa acarreta o levantamento de dados de várias fontes que está restrita a documentos escritos ou não, de fontes primarias ou não. Este trabalho se baseia em coleta de dados de documentos escritos primários (documentos públicos e privados) e secundários (relatórios, estudos, pesquisa estatística).

E por fim a análise de dados em que afirma Prodanov e Freitas (2013) é identificar os procedimentos adotados para ter informações dos dados obtidos. Ao mesmo tempo que para Marconi \& Lakatos (2003) é nesta fase que são expostas as evidências à verificação das hipóteses. Consequentemente com os questionários respondidos, foi feita a interpretação dos dados coletados para compreender a real situação em que se encontra sobre o tema.

\section{ANÁLISE DE DADOS}

Na delimitação do campo destinado a coleta de dados foi utilizado o critério territorial que consiste nos limites municipais da cidade de Boa Vista, capital de Roraima. Os registros dos escritórios de contabilidade no Conselho Regional de Contabilidade de Roraima (CRC-RR) também foi um fator delimitante do campo de pesquisa, visto que, a coleta de dados utilizou como universo o total de escritórios regularmente inscritos no referido conselho de fiscalização no ano de 2019.

Gráfico 01 - Universo de escritórios de contabilidade em Boa Vista - RR.

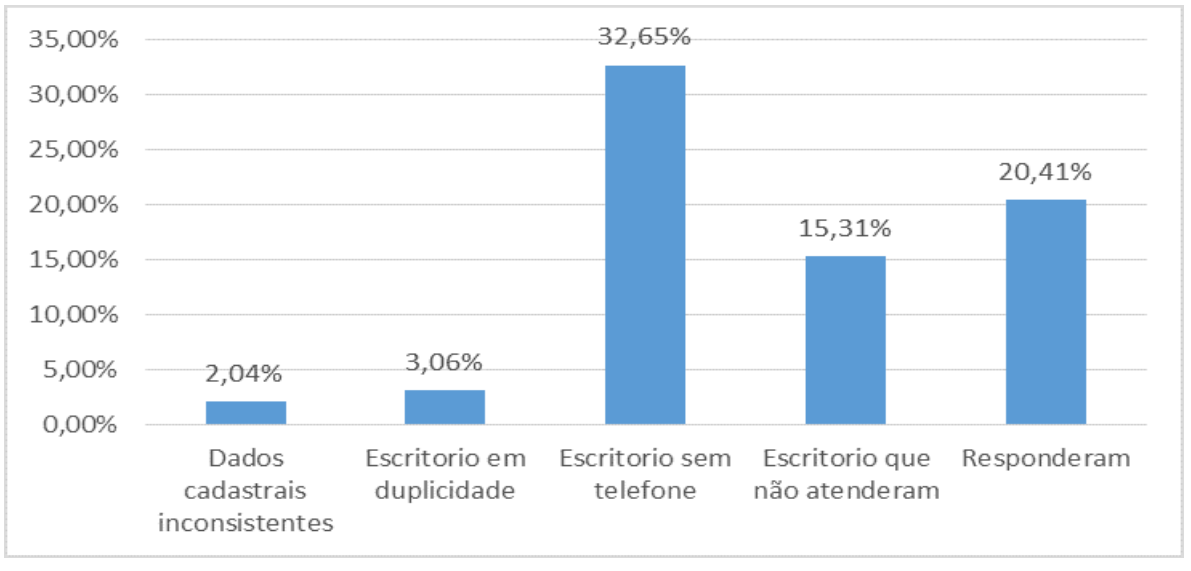

Fonte: Elaborado pelos autores (2019) 
O citado universo perfaz um total de 98 de escritórios de contabilidade com regular inscrição no CRC-RR, dentre os quais foi colida, durante o período de 09 a 24 de maio de 2019 a amostragem de $20,41 \%$ que efetivamente forneceram os dados analisados neste artigo.

Interessante destacar que, o convite para participar da pesquisa em tela seria igualmente encaminhado a todos os escritórios registrados no CRC-RR. No entanto, surgiram impedimentos de origem administrativa e organizacional do CRC-RR, que, por isso impossibilitaram ampliar o percentual de amostragem nesse estudo.

Tem-se os surpreendentes dados percentuais de 32,65\% de escritórios com telefones não registrados no CRC-RR. Além do que $3,06 \%$ dos estabelecimentos foram registrados em duplicidade. Somando-se a esses números ainda se tem que 2,04\% dos escritórios registrados no $C R C$ tem dados cadastrais inconsistentes e 15,31\% não atenderam as tentativas do contato telefônico.

Portanto, a amostragem percentual de 20,41\%, que perfaz um total de 20 escritórios contábeis regularmente inscritos no CRC-RR, forneceu uma diversidade de informações tanto de caráter objetivo quanto de caráter subjetivo, a seguir minuciosamente analisados.

Gráfico 02 - Quantitativo de contribuintes que optam pelo modelo completo.

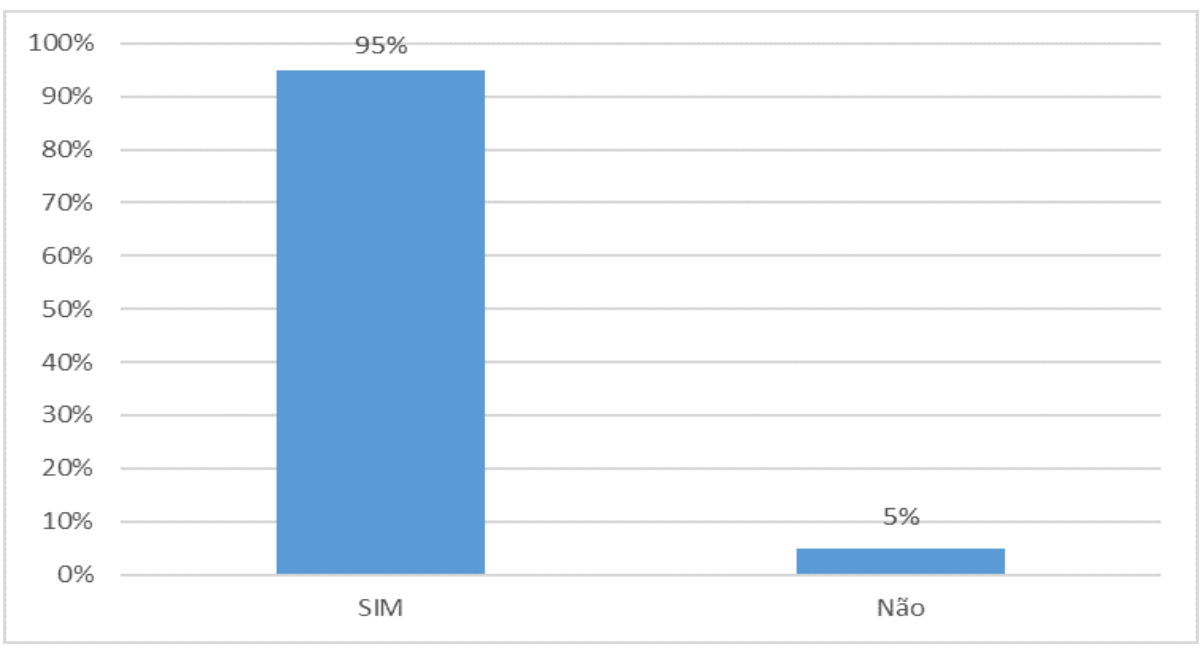

Fonte: Elaborado pelos autores (2019) 
A primeira pergunta que compõe o questionário "Você elabora a declaração do imposto de renda pessoa física - DIRPF, também no modelo completo para seus clientes? " Consiste em saber se o contador efetivamente realiza em seu cotidiano profissional a declaração do imposto de renda pessoa física no modelo completo. Dentre os entrevistados, responderam positivamente a essa pergunta $95 \%$ e apenas $5 \%$ informaram não realizar a DIRF na modalidade completa.

A relevância dessa informação consiste no fato de que apenas na DIRF no modelo completo o contribuinte tem acesso a opção de realizar a doação de parte de seu imposto as instituições destinadas aos trabalhos assistenciais.

Gráfico 03 - Número, aproximado, de clientes que realizam declaração do IRPF no escritório dos pesquisados.

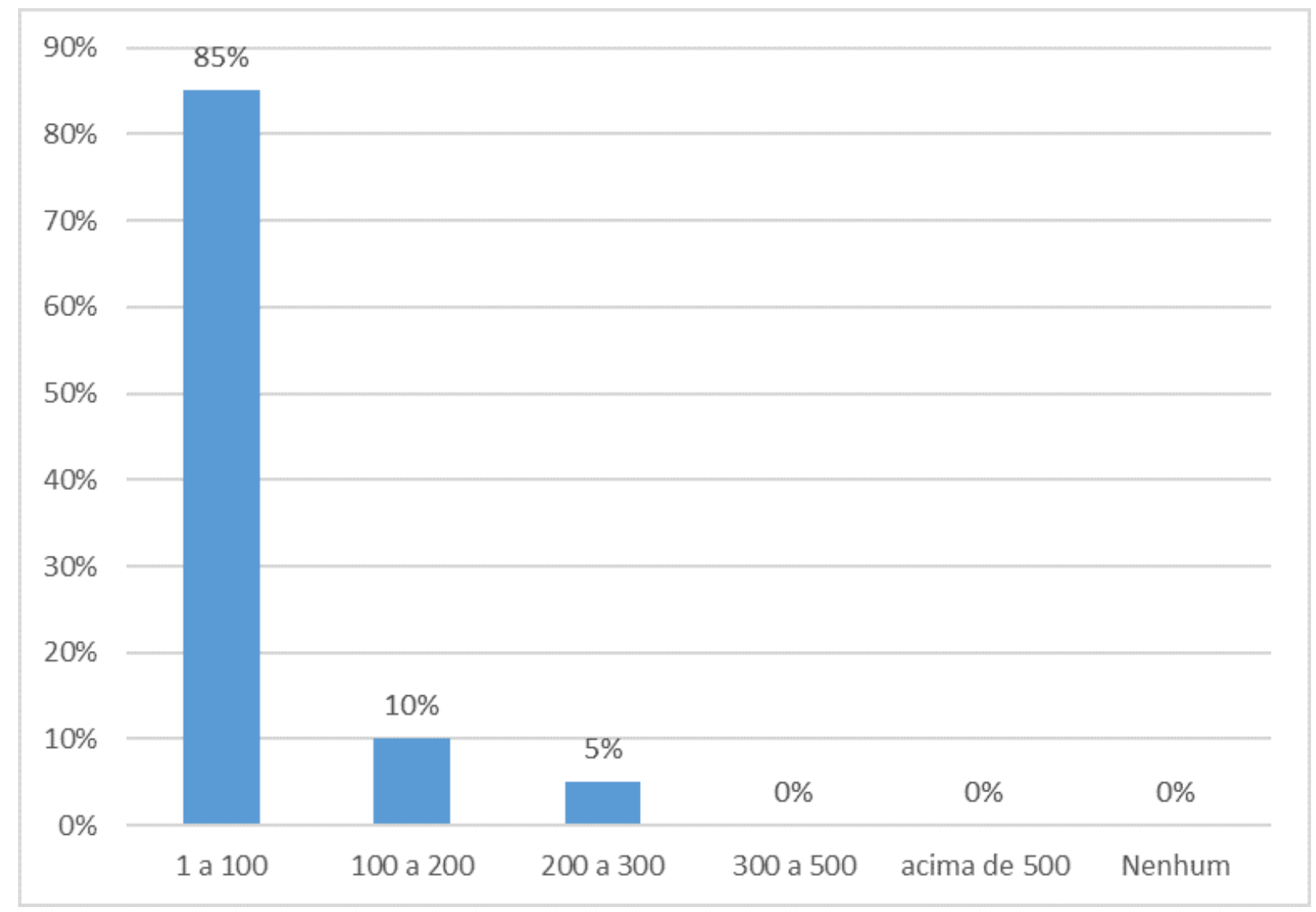

Fonte: Elaborado pelos autores (2019) 
A segunda pergunta do questionário de entrevista denota de forma esmagadora que é preponderante na cidade de Boa Vista-RR os escritórios contábeis de pequeno porte, ou seja, escritórios que possuem uma carteira contando com no máximo 100 clientes.

Fato este, condizente, com a estrutura populacional da cidade, visto que, apesar de ser uma capital, é uma região com baixa densidade demográfica e com apenas 28,5\% da população considerada ocupada, segundo dados do IBGE-2016

Deste modo, à vista da pergunta: "Aproximadamente qual é o número de clientes que realizam a declaração de IRPF na sua empresa?" Não foi inesperado que $85 \%$ dos entrevistados responderam que sua carteira de cientes fica entre 1 e 100 pessoas.

Gráfico 04 - Clientes que realizam declarações com doações incentivadas.

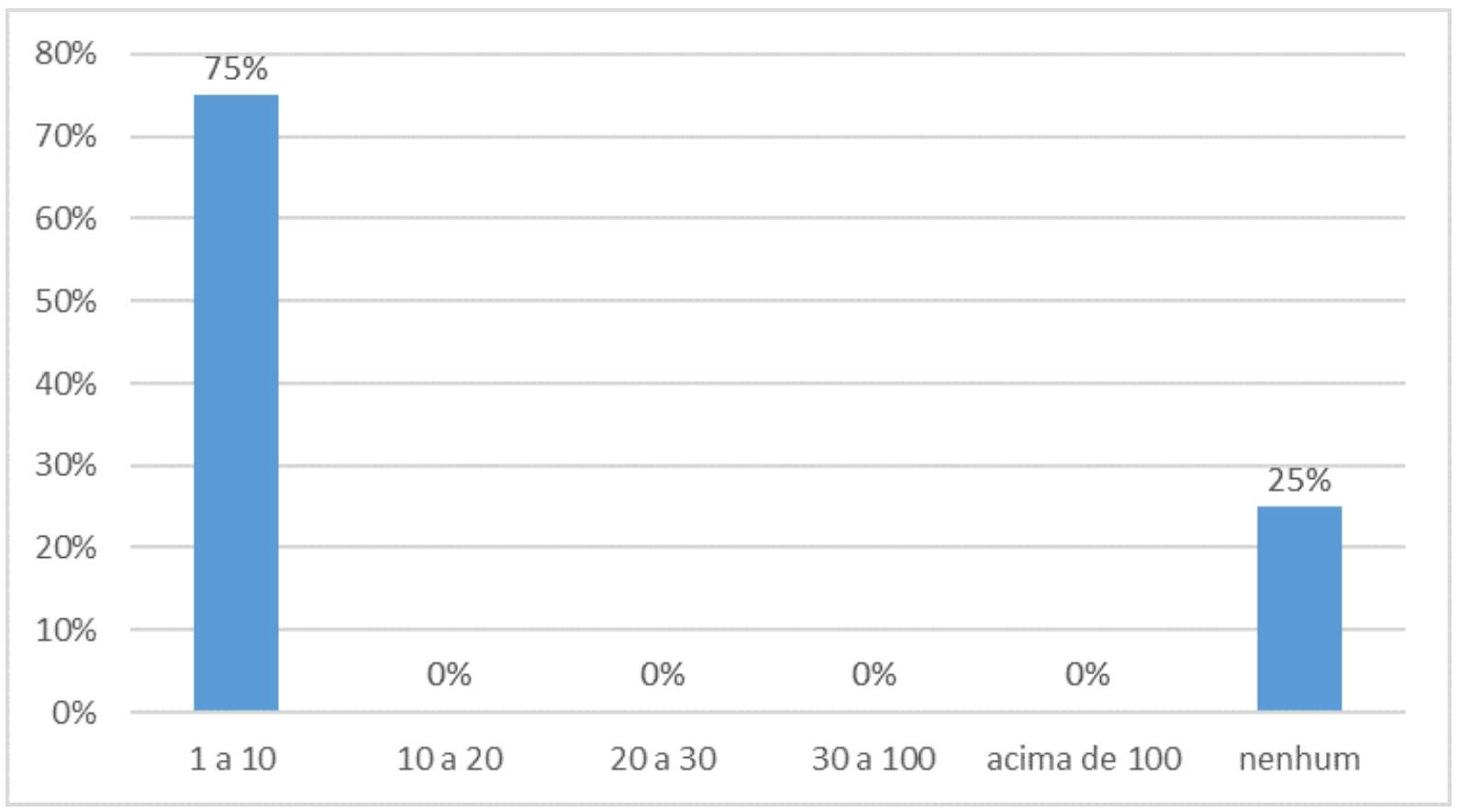

Fonte: Elaborado pelos autores (2019)

"Quantos clientes realizam declarações com doações incentivadas? " Mediante este questionamento, os $75 \%$ dos contadores entrevistados afirmaram que do seu universo de clientes apenas entre $1-10$ realizam as doações incentivadas. 
Lembrando que carteira de clientes declarada por $85 \%$ dos contadores na pergunta anterior fica entre 1 e 100 pessoas, a proporção dentre eles que realizam as doações incentivadas demonstra-se extremamente ínfima, ou seja, no universo de declarantes do IRPF aqueles que se dispõe a realizar as doações são pouquíssimos.

Assim, havendo o incentivo por parte dos contadores o número de doadores pode ser bastante ampliado dentre aqueles que efetivam as declarações.

Gráfico 05 - Tempo de atuação como contador.

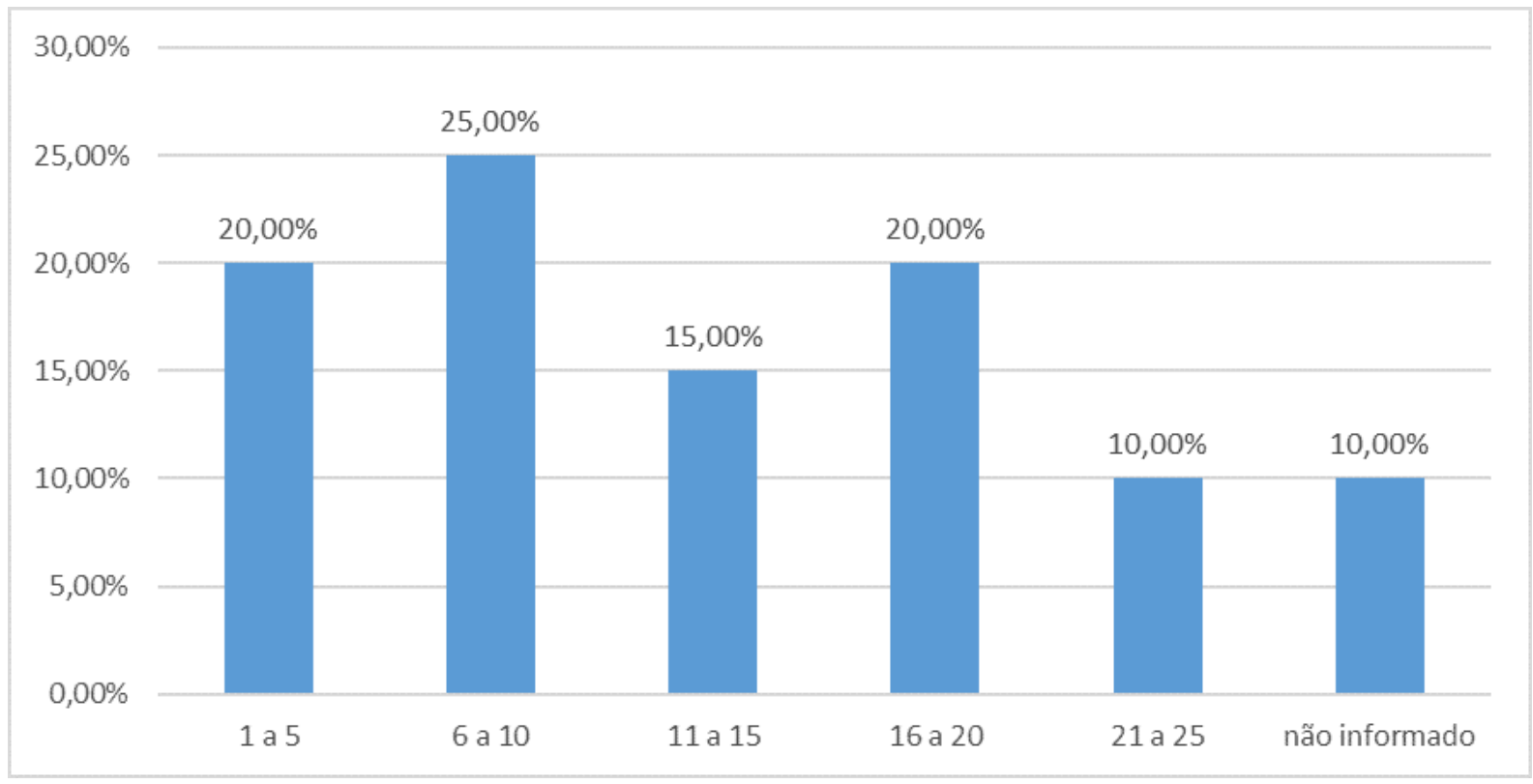

Fonte: Elaborado pelos autores (2019)

No momento em que os entrevistados foram questionados sobre sua experiência profissional, ficou evidente que predominam profissionais com ampla experiência na área contábil.

Visto que, frente a pergunta: "Quanto tempo você atua como contador?", o percentual de $25 \%$ dos entrevistados relatam ter entre 6 a 10 anos de experiência. Por outro lado $15 \%$, dos entrevistados responderam que possuem entre 11 a 15 anos de atividade neste campo de atuação. Além do que, 20\% afirmam possuir acima de 20 anos de experiência profissional. 
Apenas, $20 \%$ possuem pouca experiência profissional prática na área contábil entre 1 a 5 anos. Portanto, a maioria absoluta dos profissionais possuem vasta experiência em se tratando de atuar com as DIRF no modelo completo que possibilita a doação voluntária de parte do IR à instituições de cunho social.

Gráfico 06 - Quantitativo de contribuintes informados sobre a alternativa de realizar doações do imposto a pagar na própria declaração.

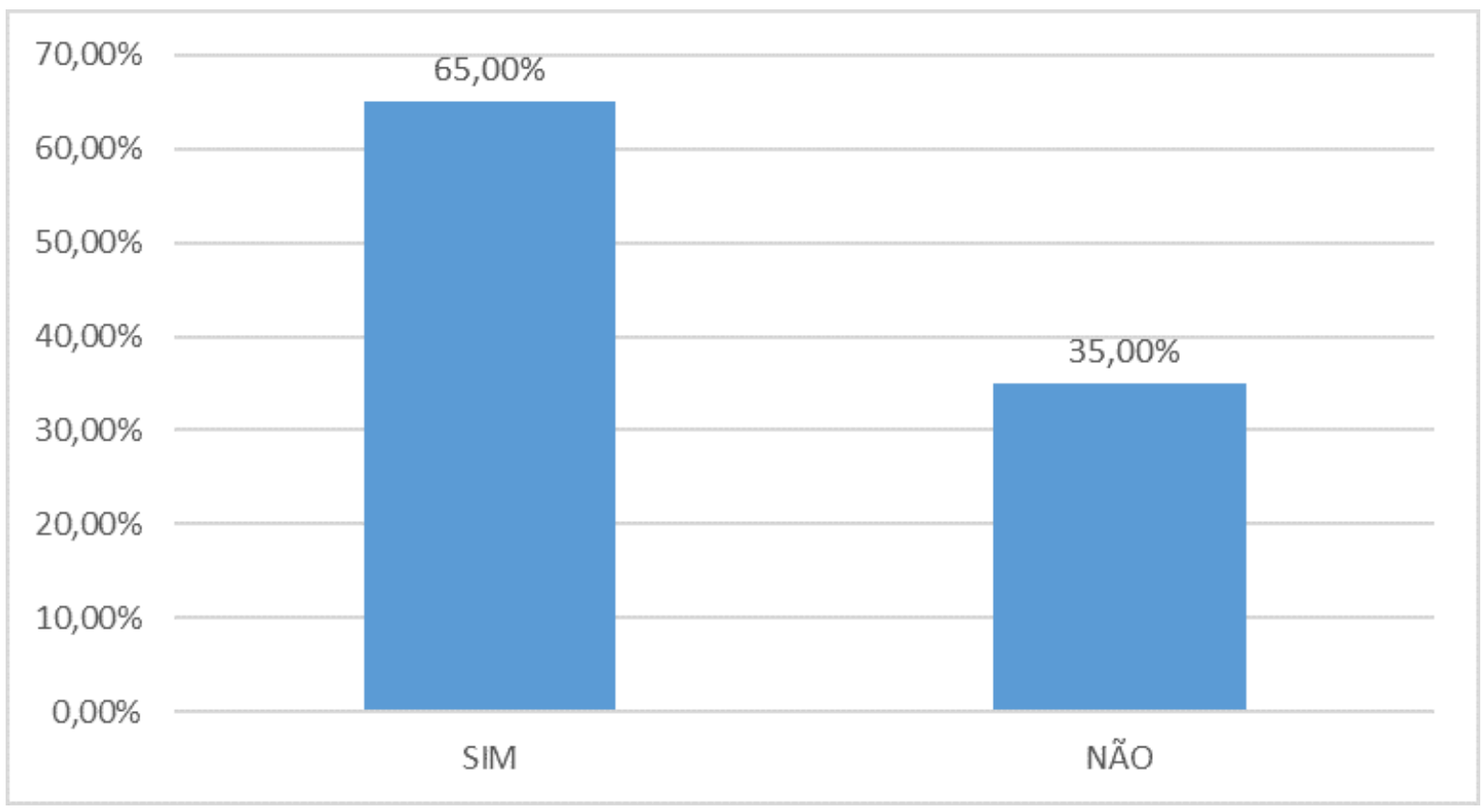

Fonte: Elaborado pelos autores (2019)

O profissional entrevistado foi questionado se "Você informa aos seus clientes que optam por DIRF COMPLETA a alternativa de realizar doações através da DIRPF?". E mais da metade dos profissionais, ou seja, $65 \%$ dos escritórios de contabilidade afirmaram que apresentam ao contribuinte a opção de realizar a DIRF completa com doação incentivada.

No entanto, o percentual de 35\% dosescritórios que não repassam aos seus clientes a informação ainda é muito alto, mesmo porque, como foi possível constatar anteriormente, o universo que compõe os escritórios contábeis registados no $\mathrm{CRC}$ em Boa Vista- RR prepondera profissionais com vasta experiência, portanto, com amplo conhecimento para orientar seus clientes quanto a doação incentivada. 
Como justificativa para não informar sobre a doação incentivada foi levantada a questão da dificuldade na disponibilização dos dados das entidades que podem receber o recurso e que realizam poucas declarações, sendo que no geral, não há nada a restituir ou a pagar.

Gráfico 07 - Incentivos fiscais conhecidos pelos escritórios de contabilidade

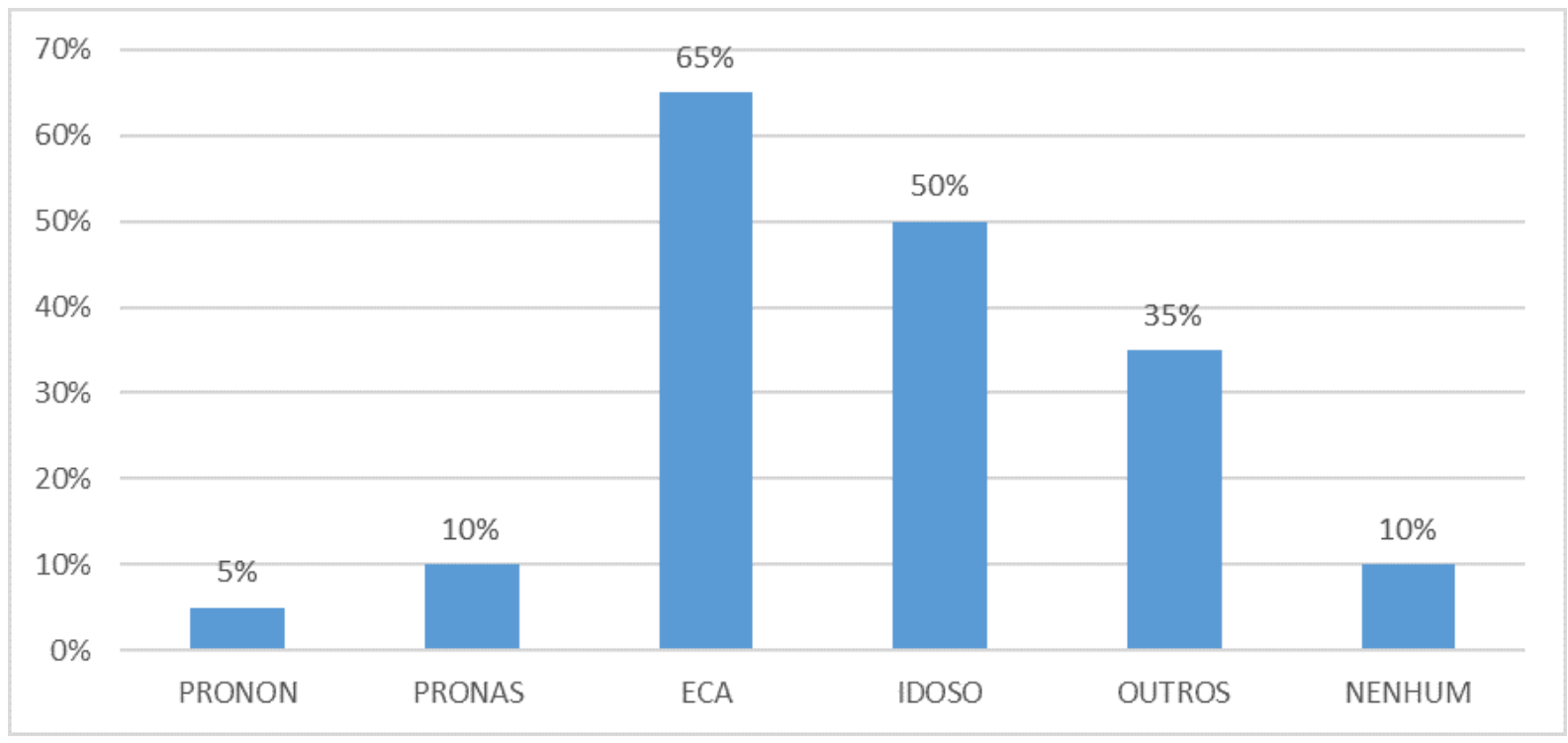

Fonte: Elaborado pelos autores (2019)

Os entrevistados foram expostos a seguinte pergunta "Quais desses incentivos fiscais você conhece?" E foram apresentados como alternativa o PRONON (Programa Nacional de Apoio à Atenção Oncológica), o PRONAS/PCD (Programa Nacional de Apoio d Atenção da Saúde da Pessoa com Deficiência), o Fundo do Direito da Criança e Adolescente, o Estatuto do Idoso, a opção outros e a opção nenhum.

Os profissionais nesse quesito optaram por mais de um programa de incentivos fiscais como de seu conhecimento. O Fundo do Direito da Criança e Adolescente é de conhecimento de $65 \%$ dos profissionais e o do Estatuto do Idoso é de conhecimento de $50 \%$ dos entrevistados.

Os programas de incentivos fiscais menos conhecidos são PRONON (Programa Nacional de Apoio à Atenção Oncológica), apenas 5\% o conhecem e o PRONAS/PCD (Programa Nacional de Apoio de Atenção da Saúde da Pessoa com Deficiência) é 
conhecido por apenas $10 \%$. E ainda $35 \%$ dos pesquisados informaram conhecer outros programas além dos apresentados no questionário, mas sem identificar quais.

E ainda $10 \%$ dos escritórios profissionais contábeis que atuam em Boa Vista-RR afirmaram não conhecer nenhum programa social que possa ser beneficiado pelos recursos da doação incentivada através do DIRF.

Gráfico 08 - Papel do contador ao informar aos contribuintes sobre as doações através da DIRPF.

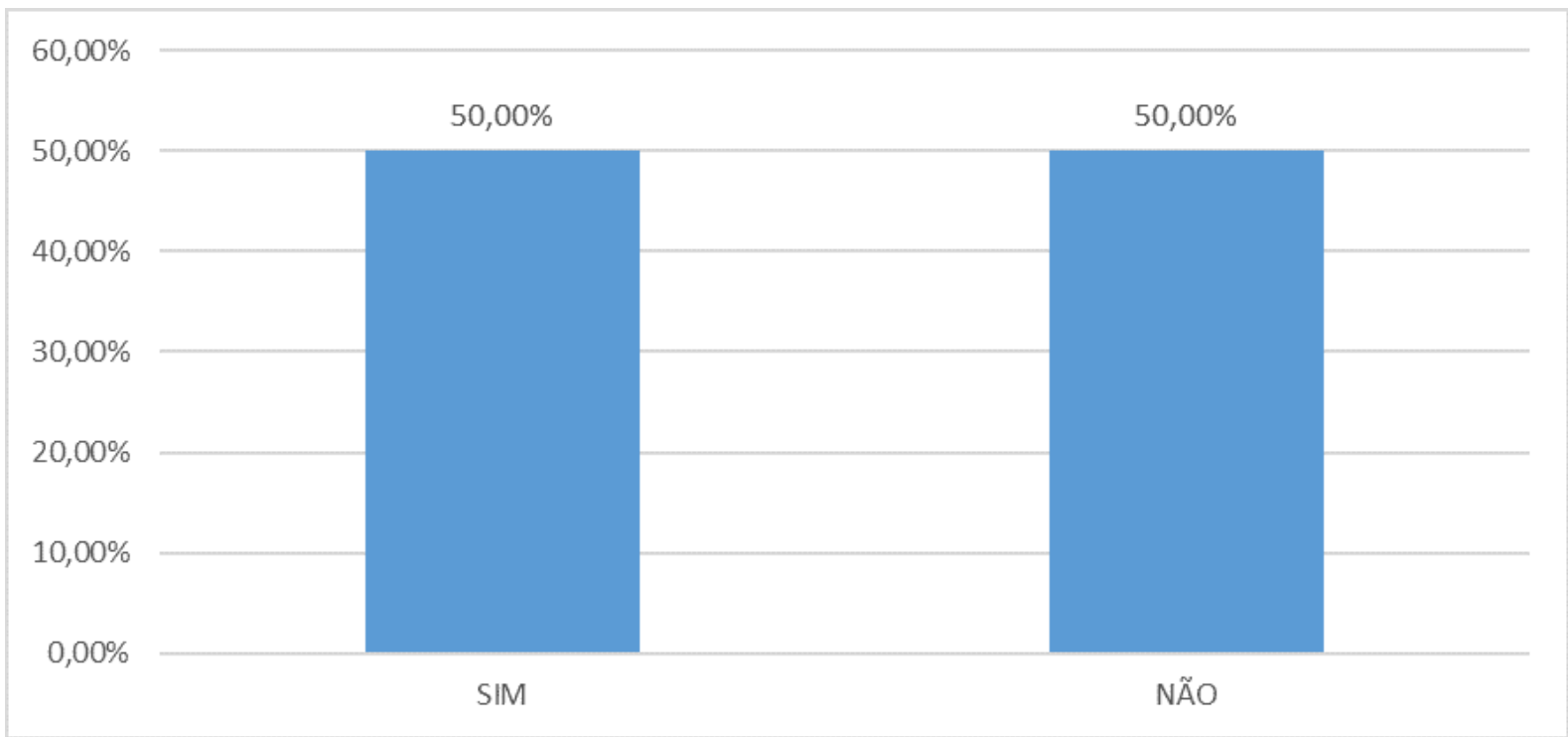

Fonte: Elaborado pelos autores (2019)

O pesquisado foi questionado sobre a situação mais importante para este artigo: "Em sua opinião é papel do contador informar aos contribuintes sobre as doações através da DIRPF?".

Diante desta questão, $50 \%$ dos pesquisados responderam que é responsabilidade do contador informar aos contribuintes sobre as doações através da DIRPF e utilizaram justificativas que demonstram que possuem consciência de sua responsabilidade como contadores e como cidadãos capazes de contribuir para melhoria social. 
Eis algumas das brilhantes justificativas: "é de responsabilidade do contador", "pois a maioria não tem conhecimento sobre o tema", "é uma prática solidária, que contribui para sociedade", "ajuda social como papel ativo do profissional" entre outros.

No entanto, os outros $50 \%$ dos pesquisados responderam que não identificam como responsabilidade do contador informar aos contribuintes sobre as doações incentivadas através da DIRPF.

Como justificativa apresentaram os seguintes argumentos dentre outros: "porque isso não e papel exclusivo do contador", "a orientação e divulgação deve ser feita por parte do interessado". "Não pode ser orientado, pela dificuldade de tempo e por alguns apresentarem a declaração em cima da hora as vezes não orientamos o contribuinte" dentre outras.

Gráfico 09 - A responsabilidade das entidades sociais pela falta de doações no Estado.

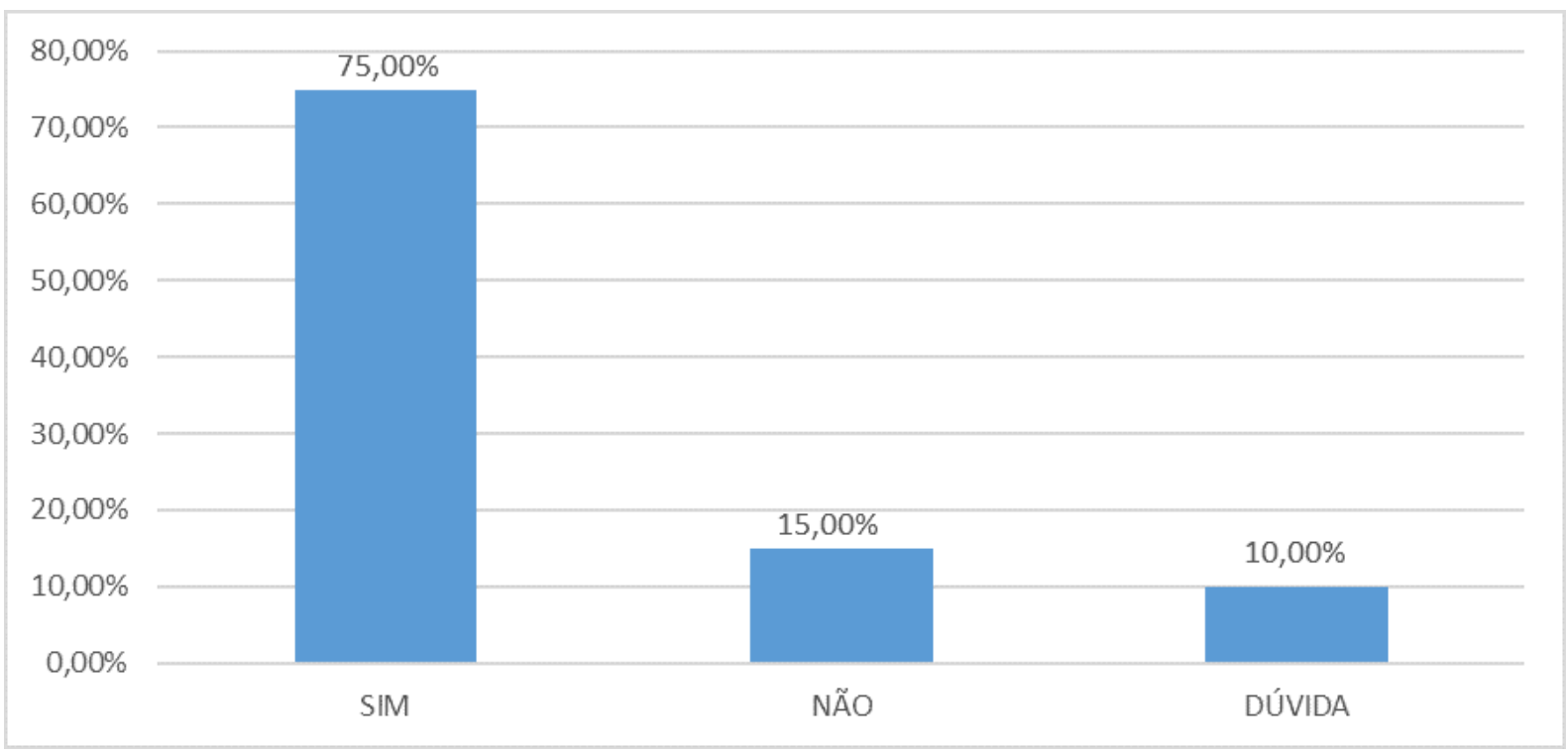

Fonte: Elaborado pelos autores (2019)

Quando questionados sobre "Em sua opinião as entidades sociais também podem ser responsáveis pela falta de doações no Estado?", expressivos $75 \%$ os entrevistados afirmaram que sim, que a falta de divulgação por parte das entidades sociais influi negativamente nas doações incentivadas dos contribuintes. 
E utilizaram as seguintes justificativas: "não divulgam", "Mal assessoradas", "não deixam clara a informação que elas podem receber recursos, poderia ter uma campanha no primeiro mês de envio do IRPF", "deviam fazer ações de esclarecimentos e regularização das entidades beneficiadas" entre outras.

Assim, como os $15 \%$ que dizem que não é responsabilidade das entidades sociais divulgar tais informações justificam-se afirmando que "porque isso não depende só do estado, mais sim do contribuinte querer ou não doar" e ainda há $10 \%$ dos entrevistados que não sabem opinar sobre o assunto.

Gráfico 10 - Papel do escritórios de contabilidade como incentivador social.

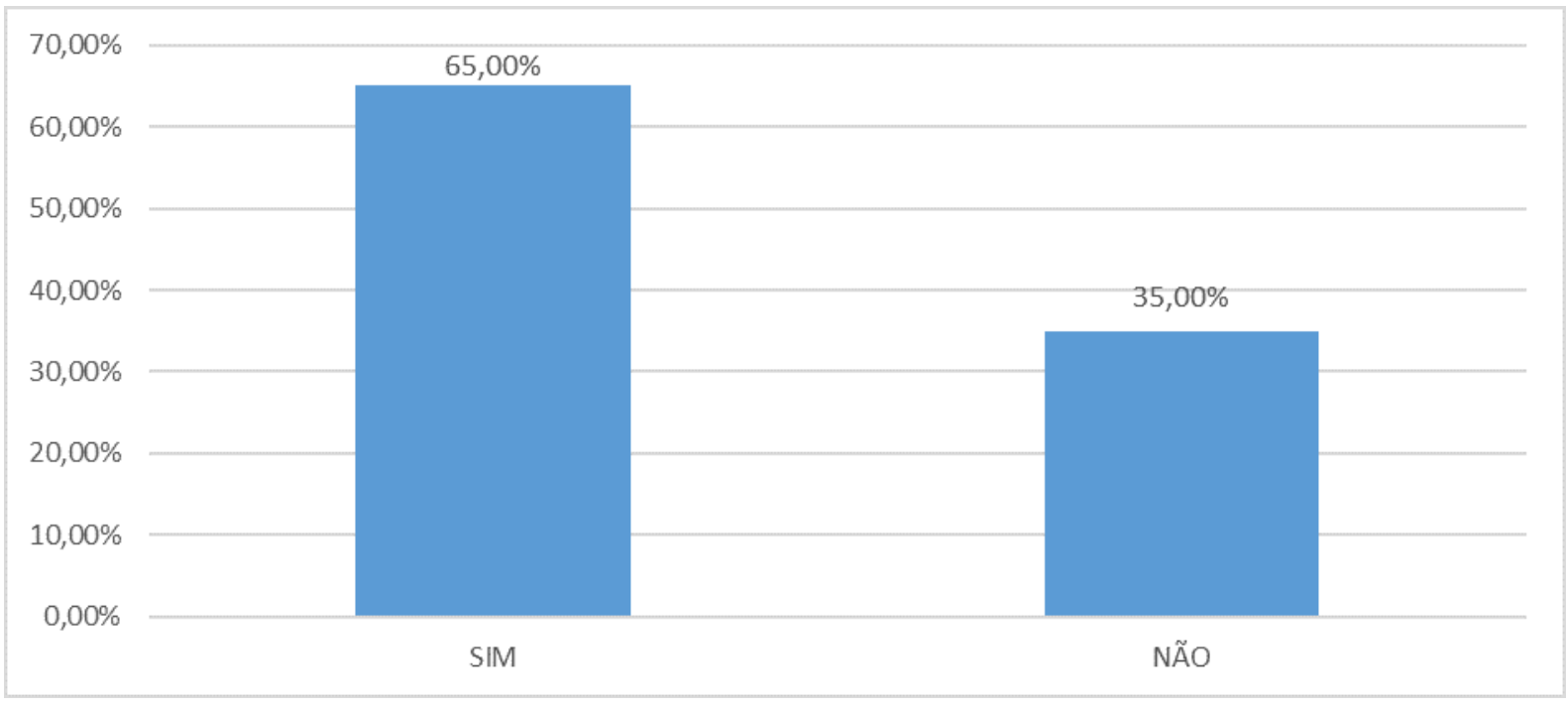

Fonte: Elaborado pelos autores (2019)

Frente ao questionamento: "Ao motivar seus clientes a realizar doações através da DIRPF, você se sente um motivador social?". O pesquisado precisou refletir sobre seu papel como motivador social e a maioria, isto é, $65 \%$ identificaram-se como um incentivador social. No entanto, $35 \%$ não percebem que esse é um dos seus papéis como profissional contábil. 
Gráfico 11 - Dificuldade em realizar doações.

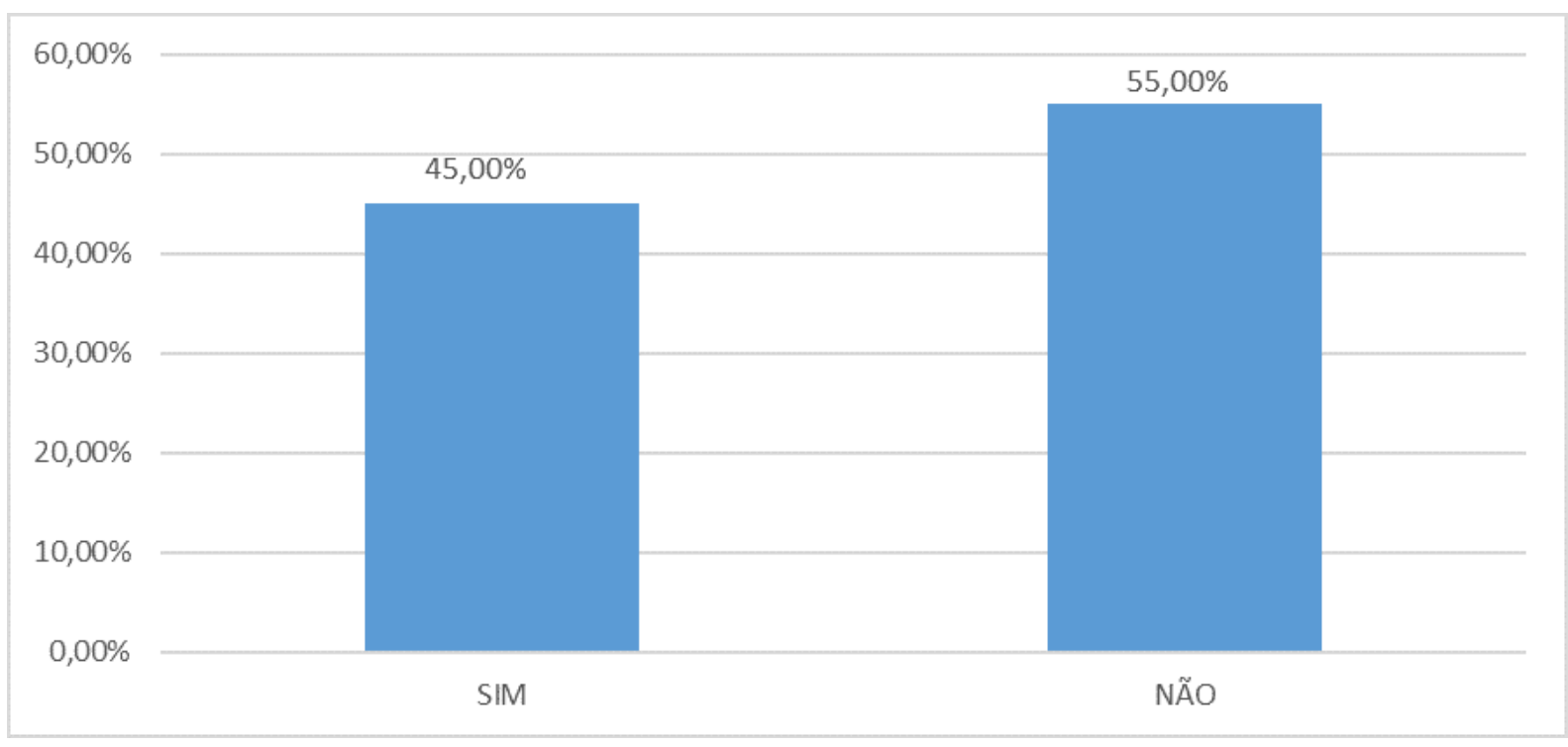

Fonte: Elaborado pelos autores (2019)

Diante da pergunta "Em sua opinião, na elaboração da DIRPF, existe alguma dificuldade para realizar as doações?" foi identificado que a maioria não identifica nenhuma dificuldade para realizar a doação durante a elaboração da DIRF, isto é, para 55\% não há dificuldades.

Mas, para $45 \%$ dos entrevistados há dificuldades e elas consistem em "falta de engajamento e campanhas". "A maioria (das entidades) não está apta para receber as doações", "falta de informação", "poderia ser menos burocrático" dentre outras. 
Gráfico 12 - Escritórios de contabilidade que procuram conhecer as entidades sociais

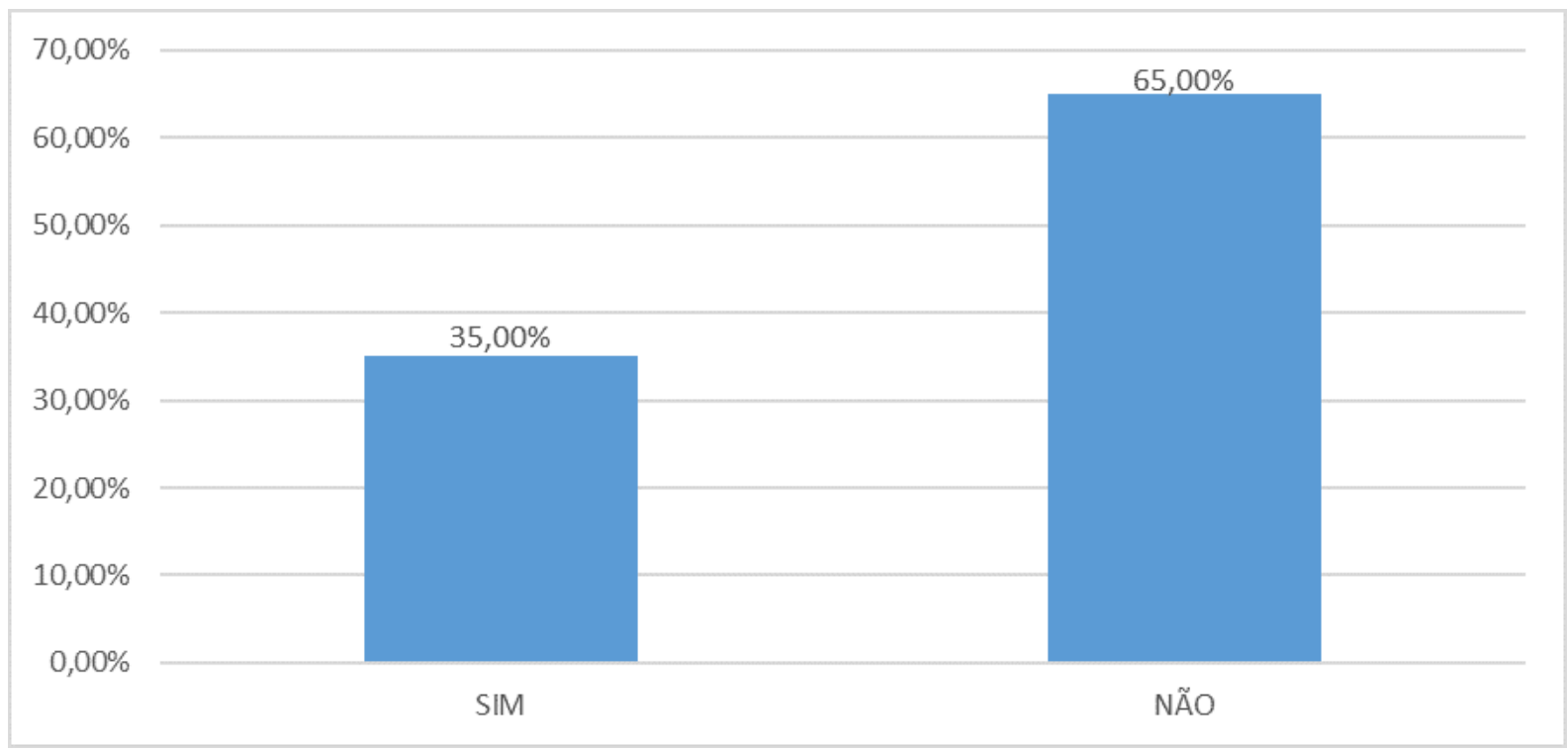

Fonte: Elaborado pelos autores (2019)

Sobre o item "Você busca conhecer as entidades sociais que estão aptas a receber doações?" os contadores que se identificaram como proativos no momento de buscar informações perfazem um total percentual de $35 \%$ frente a $65 \%$ que se demonstraram não proativos na busca dessas informações.

Essa falta de iniciativa na busca de novas informações no tocante a doação incentivada foi justificada pela "falta de tempo, o escritório exige muito, a profissão contábil não é muito valorizada e por isso tem muito serviço e pouco retorno", "por falta de tempo" e por falta de "interesse".

No entanto, uma resposta chamou a atenção. O pesquisado afirmou que "não tinha despertado para essa realidade", o que reflete uma questão mais de base, ou seja, enquanto ainda aluno de contabilidade a responsabilidade social do contador não é um tema abordado com ênfase durante o curso universitário. 
Gráfico 13 - Interferência na decisão do contribuinte na adesão das doações na DIRPF.

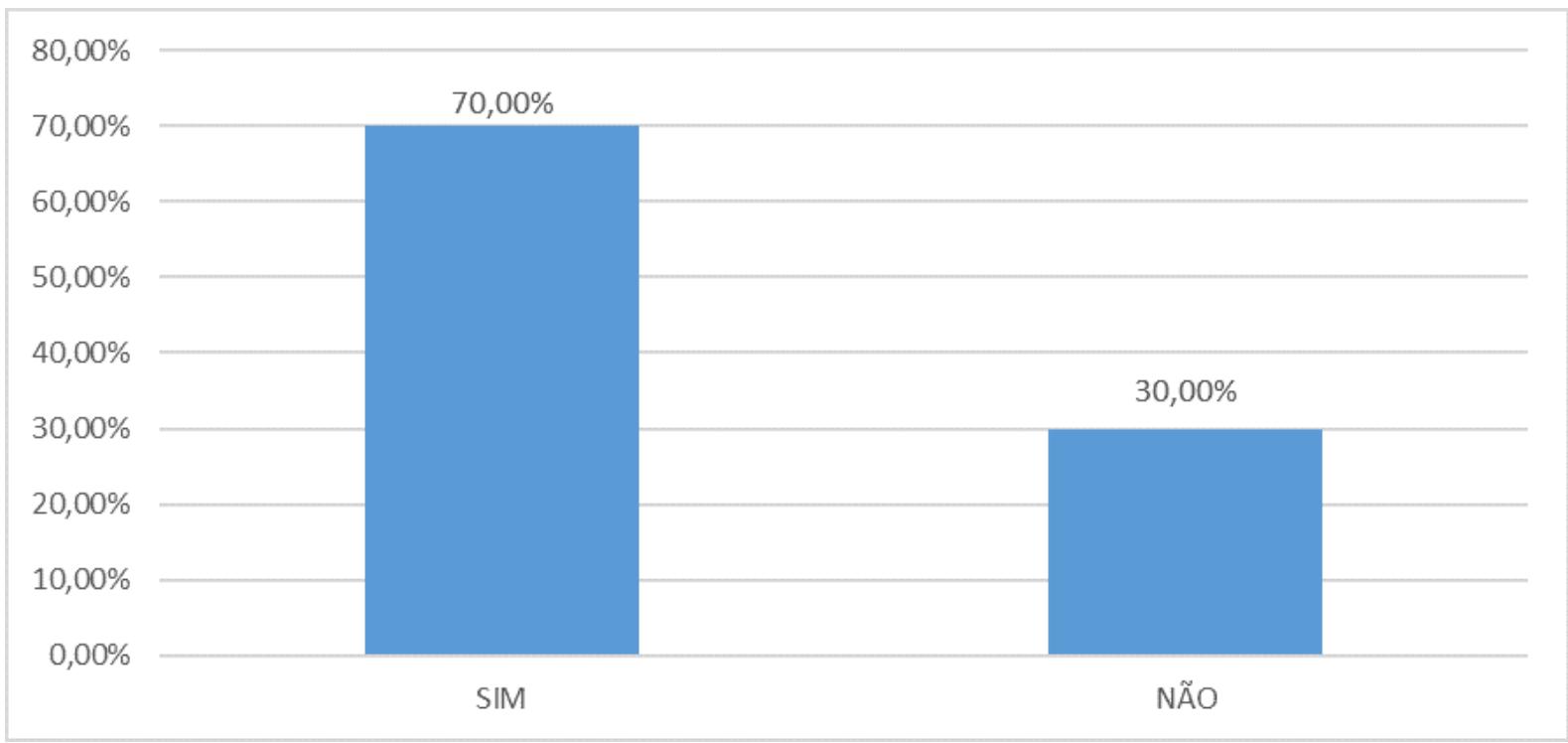

Fonte: Elaborado pelos autores (2019)

No tocante a influência do contador como profissional foi questionado "Em sua opinião, existe algum motivo que possa interferir na decisão do seu cliente, na adesão das doações na DIRPF?". A minoria respondeu que não, o que corresponde a $30 \%$ dos pesquisados. E, em contrapartida, $70 \%$ responderam que sim e fundamentaram suas respostas dizendo que é em razão da "ausência de transparência na aplicação dos recursos", pelo "receio de fiscalizações", pelas "fraudes e desvios divulgados pela imprensa", pela "falta de conhecimento" entre outras. 
Gráfico 14 - Papel do Conselho Regional de Contabilidade na divulgação de campanhas para doações incentivadas.

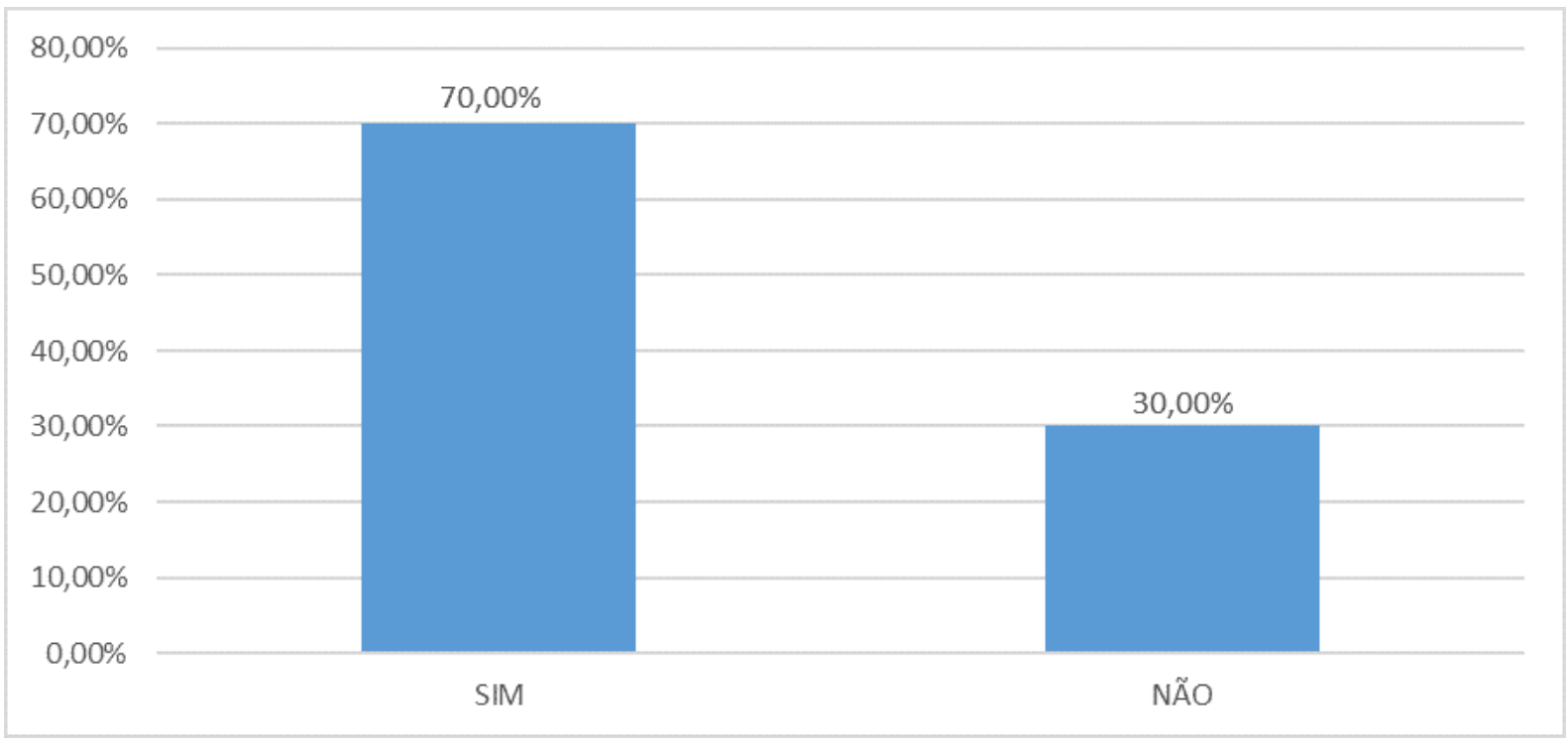

Fonte: Elaborado pelos autores (2019)

Quando perguntado "Em sua opinião é importante que o Conselho Regional de Contabilidade CRC faça campanhas para o público em geral, voltadas às doações através do imposto a pagar na DIRPF?". O posicionamento dos entrevistados de que o CRC deve sim atuar ativamente na divulgação de informações sobre as doações incentivas foram expressos nos $70 \%$ que disseram sim. E apenas, $30 \%$ disseram que o CRC não deve atuar, pois o "trata-se de entidade de fiscalização e registro".

O CRC embora seja essencialmente um órgão fiscalizador, não se exime de ter uma posição social atuante junto aos seus associados e a sociedade em geral. Neste sentido, pode-se enfatizar a atuação do CRC do Estado do Rio Grande do Sul que oferece formação continuada e cidadã aos seus associados. Do mesmo modo, é perfeitamente aceitável e esperado que o CRC-RR atue também como agente incentivador.

\section{CONSIDERAÇÕES FINAIS}

A presente pesquisa se propôs a questionar se o contador exerce o papel de incentivador no exercício da cidadania fiscal, mediante a aplicação de deduções na 
DIRPF em Boa Vista - RR? Sendo um campo inexplorado na área geográfica de delimitação da temática, a proposta surgiu com um grau de complexidade muito grande.

Uma das barreiras para a realização da pesquisa foi a dificuldade de acesso a informação. A Receita Federal seria uma fonte riquíssima de informação, no entanto, foi encaminhado ofício ao órgão solicitando informações sobre quantidade de declarações de IRPF contendo os valores percentuais de declarantes que utilizam os dois tipos de modelo disponíveis de declaração, isto é, o simplificado e completo, com base nos exercícios de 2017 e 2018. Porém, esses dados não foram disponibilizados.

No entanto, a relevância social do estudo que contribui para compreender a prática de doações como incentivo para realizações de projetos sociais em Boa Vista/Roraima foi a motivação para que todas as etapas da pesquisa fossem concretizadas.

E assim, apreende-se que, os serviços públicos federais, estaduais e municipais ofertados à população (saúde, educação, cultura, esporte e outros) são deficitários e insuficientes para atender à crescente demanda social, muito embora a função social do IR seja a redistribuição da Renda que é aplicada na gestão de tais serviços.

E o profissional que atua diretamente com a DIRF é o contador que, infelizmente não se vê como um agente social ativo e com oportunidade, durante a sua prática profissional, de informar e orientar o contribuinte quanto as suas opções em realizar a doação incentivada.

Lamentavelmente, a realidade refletida em Boa Vista-RR é que, 35\% dos profissionais não se identificam como responsáveis por informar aos contribuintes sobre as doações incentivadas por meio da DIRPF. E, simplesmente passam a responsabilidade adiante com alegações como falta de tempo e pouco retorno financeiro.

Além do mais, 35\% dos profissionais afirmam categoricamente que não repassam aos seus clientes a informação sobre a doação incentivada, apesar de, em Boa Vista - 
RR, prepondera profissionais com vasta experiência, portanto, com amplo conhecimento para orientar seus clientes quanto as referidas doações.

Então, não é de se surpreender que a quantidade de contribuintes que realizam a doação incentivada seja tão ínfima em Boa Vista. Pois, apenas é o reflexo do posicionamento dos profissionais que deveriam ser o motor social dessas doações.

No entanto, as origens deste cenário podem ser mais profundas e terem sua origem ainda nos bancos da universidade. Esta relevante possibilidade foi arguida, de forma indireta, por um dos pesquisados ao afirmar que "não tinha despertado para essa realidade". Ora, se o profissional experiente até então não havia despertado para a sua responsabilidade social enquanto contador é porque ainda como aluno de contabilidade o tema não Ihe foi suscitado com eficiência durante o curso universitário.

Eis que, a profissão contábil está fortemente ligada com a responsabilidade da sensibilização e divulgação das doações que beneficiam o desenvolvimento socioeconômico não apenas em Boa Vista-RR. O contador é referência para os contribuintes do Imposto de Renda, pois é portador do conhecimento para a elaboração da declaração da renda, por isso, necessita ser proativo e identificar-se como um agente de modificação social.

Sendo ainda necessário repensar a prática acadêmica em que toda a estrutura do profissional é erigida. Desenvolvendo o olhar do futuro profissional sobre si mesmo como detentor do conhecimento que pode sim fazer a diferença no bem-estar social.

\section{REFERÊNCIAS}

ALENCAR JUNIOR, Osmar Gomes; SALVADOR, Evilásio da Silva. Finanças público e financiamento da seguridade social no brasil. Revista Katálysis. Florianópolis, v. 18, n. 2, p. 239-248, jul./dez. 2015

AMARO, Luciano. Direito tributário brasileiro. São Paulo: Saraiva, 2017. 
BEUREN, Ilse Maria. Como elaborar trabalhos monográficos em contabilidade: teoria e prática. 3. ed. São Paulo: Atlas, 2006.

BRASIL. LEI № 8.069, DE 13 DE JULHO DE 1990. Dispõe sobre o Estatuto da Criança e do Adolescente e dá outras providências publicado no DOU 16.7.1990 e retificado em 27.9.1990.Seção 1 - 16/7/1990, Página 13563

BRASIL. LEI № 12.213, DE 20 DE JANEIRO DE 2010. Institui o Fundo Nacional do Idoso e autoriza deduzir do imposto de renda devido pelas pessoas físicas e jurídicas as doações efetuadas aos Fundos Municipais, Estaduais e Nacional do Idoso; e altera a Lei no 9.250, de 26 de dezembro de 1995. Diário Oficial da União - Seção 1 - 21/1/2010, Página 2

BRASIL. LEI № 8.242, DE 12 DE OUTUBRO DE 1991. Cria o Conselho Nacional dos Direitos da Criança e do Adolescente (Conanda) e dá outras providências. Diário Oficial da União - Seção 1 - 16/10/1991, Página 22589

BRASIL. LEI № 12.715, DE 17 DE SETEMBRO DE 2012. Altera a alíquota das contribuições previdenciárias sobre a folha de salários devidas pelas empresas que especifica; institui o Programa de Incentivo à Inovação Tecnológica e Adensamento da Cadeia Produtiva de Veículos Automotores, o Regime Especial de Tributação do Programa Nacional de Banda Larga para Implantação de Redes de Telecomunicações, o Regime Especial de Incentivo a Computadores para Uso Educacional, o Programa Nacional de Apoio à Atenção Oncológica e o Programa Nacional de Apoio à Atenção da Saúde da Pessoa com Deficiência; restabelece o Programa Um Computador por Aluno; altera o Programa de Apoio ao Desenvolvimento Tecnológico da Indústria de Semicondutores, instituído pela Lei no 11.484, de 31 de maio de 2007; altera as Leis no s 9.250, de 26 de dezembro de 1995, 11.033, de 21 de dezembro de 2004, 9.430, de 27 de dezembro de 1996, 10.865, de 30 de abril de 2004, 11.774, de 17 de setembro de 2008, 12.546, de 14 de dezembro de 2011, 11.484, de 31 de maio de 2007, 10.637, de 30 de dezembro de 2002, 11.196, de 21 de novembro de 2005, 10.406, de 10 de janeiro de 2002, 9.532, de 10 de dezembro de 1997, 12.431, de 24 de junho de 2011, 12.414, de 9 de junho de 2011, 
8.666, de 21 de junho de 1993, 10.925, de 23 de julho de 2004, os Decretos-Leis no s 1.455, de 7 de abril de 1976, 1.593, de 21 de dezembro de 1977, e a Medida Provisória ํo 2.199-14, de 24 de agosto de 2001; e dá outras providências. Diário Oficial da União - Seção 1 - 18/9/2012, Página 1.

BRASIL. Constituição Federal. Brasília: Senado Federal,1988.

BRASIL. Código tributário nacional. 2. ed. - Brasília: Senado Federal, Subsecretaria de Edições Técnicas, 2012

BARREIRINHAS, Robinson Sakiyana. Como se preparar para o exame de ordem, 1a fase: tributário. 11 ed. eletrônica. Rio de janeiro: Forense. São Paulo: Método,2014.

CASTARDO, Hamilton Fernando. Direito tributário na prática. 4 ed. São Paulo: Câmara Brasileira do Livro. 2017.

CHIMENTI, Ricardo Cunha. Direito tributário: com anotações sobre direito financeiro, direito orçamentário e Lei de Responsabilidade Fiscal. 15 ed. eletrônica. São Paulo:Saraiva,2012.

CHIMENTI, Ricardo Cunha. PIERRI, Andrea de Toledo. Teoria e pratica do direito tributário. 3ed. São Paulo: Saraiva, 2012.

CREPALDI, Silvio Aparecido; CREPALDI, Guilherme Simões. Orçamento público: planejamento, elaboração e controle. São Paulo: saraiva, 2013.edição eletrônica.

CONSELHO REGIONAL DE CONTABILIDADE DO RIO GRANDE DO SUL. Comissão de Estudos de Responsabilidade Social do CRC-RS. Manual de incentivos fiscais para investimentos sociais, culturais, desportivos e na saúde. 7 ed. Eletrônica. Porto alegre, 2016

CONTE, Nelton Carlos; SANTOS, Sandra Regina Toledo dos. Planejamento, orçamento e contabilidade aplicada ao setor público. Passo Fundo: Universidade de Passo Fundo, 2014. Edição eletrônica. 
FÓRUM ECONÔMICO MUNDIAL. Relatório de Competitividade Global, 2016.

GIL, Antônio Carlos. Métodos e técnicas de pesquisa social. 6 ed. São Paulo: Atlas, 2008.

GIL, Antônio Carlos. Metodologia do ensino superior. 4 ed. São Paulo: Atlas, 2011.

INSTITUTO BRASILEIRO DE GEOGRAFIA E ESTATÍSTICA. Brasil em síntese. Roraima, Boa Vista. Panorama. Brasil, 2019. Disponível em: $<$ https://cidades.ibge.gov.br/brasil/rr/boa-vista/panorama>. Acessado em 01 de maio de 2019.

MARCONI, Marina de Andrade; LAKATOS, Eva Maria. Fundamentos de metodologia científica. 5. ed. - São Paulo: Atlas 2003.

MELO, Lucilene Ferreira de. VALE, Marla Maciel do. RP3 Revista de Pesquisa em Políticas Públicas. Fundos Públicos: um estudo sobre o destino dos recursos do Fundo da Infância e Adolescia no Amazonas. Edição 6. n2(2015)

MULLER, Elza Terezinha Cordeiro; et all. Um estudo sobre a declaração de ajuste anual do imposto de renda da pessoa física com ênfase nos fundos municipais dos direitos da criança e do adolescente. In. XIV Simpósio de Excelência em Gestão e Tecnologia. Resende. Rio de janeiro 26 e 27 out. 2017.

NÓBREGA, C.B. Imposto de renda história do imposto de renda do Brasil: um enfoque da pessoa física (1922-2013). Brasília: Receita Federal, 2014.

OLIVEIRA, Claudionor dos Santos. Metodologia científica, planejamento e técnicas de pesquisa: uma visão holística do conhecimento humano. São Paulo: Editora LTR, 2000

PRODANOV, Cleber Cristiano; FREITAS, Ernani Cesar de. Metodologia do trabalho científico: métodos e técnicas da pesquisa e do trabalho acadêmico. 2. ed. eletrônica. Novo Hamburgo: Feevale,2013. 
RECEITA FEDERAL. Fundos dos Direitos da Criança e do Adolescente (FDCA) 2018 Primeiro repasse. Primeiro repasse das doações aos Fundos dos Direitos da Criança e do Adolescente, referente ao IRPF 2018. Anexo I. Brasília, 2018. Disponível em: http://sadd.receita.fazenda.gov.br/sadd-internet/pages/validadocumento.xhtml>. Acesso em 07.11.2018

SABBAG, Eduardo. Manual de direito tributário. 4 ed. São Paulo: Saraiva, 2012.

SARLET, Ingo Wolfang. Direitos fundamentais a prestações sociais e crise: algumas aproximações. Espaço Jurídico Jornal Of Law (EJJL). Joaçaba, v16, n2. p459-488, jul./dez.2015.

Enviado: Agosto, 2019.

Aprovado: Setembro, 2019. 